\title{
緑地保全活動が市民ボランティア，企業社員，NP0法人スタッフの 心理に与える影響
}

The psychological effect of green conservation activities to citizen volunteers, corporate employees and non-profit organization staff

甲野 毅

1大妻女子大学家政学部ライフデザイン学科

Tuyoshi Kouno

${ }^{1}$ Institute of Human Culture Studies, Otsuma Women's University 12 Sanban-cho, Chiyoda-ku, Tokyo, Japan 102-8357

キーワード：緑地保全活動，市民，質問紙調査，POMS

Key words : Green conservation activities, Citizen, Questionnaire survey, POMS

\begin{abstract}
抄録
本研究の目的は，緑地保全活動が市民ボランティア，企業社員，活動を運営する NP0 法人スタッフに 与える心理的影響を示すことである。そこで東京都内の 2 つのフールドにおいて，上記の 3 つの研究 対象を設定し, 6 つの尺度からなる POMS 短縮版による質問紙調査を保全活動前後に行い, 比較検証した。 その結果, NPO 法人スタッフの回答值の変化傾向を表すスタッフ型と, 企業社員と市民ボランティアの回 答值の変化傾向を表す企業市民型の 2 つのタイプに分類された。活動後調査の回答值の平均值が活動前 調査と比較し，緊張 - 不安において下降し，疲労において上昇していることは共通していたが，それ以 外の尺度では異なる結果となった。スタッフ型では，活動後調査の回答值が活動前調査と比較し，抑う つ - 落ち込み，怒り - 敵意，混乱において上昇し，活気において下降したが，企業市民型では，前者の 尺度において下降し，後者の尺度において上昇した。企業市民型では，活動したことで身体的に疲労し た以外は，森林セラピーと同様に，参加者に心理ストレスの減少や活気をもたらす傾向がある。だが， スタッフ型では，活動を運営などすることで身体的に疲労し，心理的には活気が減少し，心理ストレス 度も高くなる傾向が示された。
\end{abstract}

\section{1.はじめに}

森林セラピーは森林の中を歩くという行為であ り，成人男性や女性を対象としてその心理的，生 理的効用が明らかにされている (宮崎ら, 2014) ${ }^{[1]}$. 一方で人々の生活圈の近くにある緑地は, 薪炭燃 料を得る,または落ち葉から堆肥を作り, 畑作や稲 作に用いるなど, 人々の生活に役立ち, そこには生 活とのつながりが存在していた。だが然料革命の 到来により，薪炭の生産を主体に成り立っていた 里山林の存在意義は一気に薄れ, 現在の緑地は放 置され, 荒廃している状態である (中川, 2004) ${ }^{[2]}$. 荒廃させておくことが社会的な損失を招く場合も あるが，財政緊縮化にある地元行政による管理が 期待できない現状下では, 緑地を適切に管理して
いくためには, 地域住民等による保全活動が期待 されている．だが地域住民だけに依存することに は限界があり，新たな担い手の登場が待たれると ころである。そのためにも市民に保全活動の新た な魅力を示すことが必要になるであろう。

また市民以外の担い手として，企業社員の組織 力が注目されている．企業には本業以外の社会貢 献活動が求められ，様々な業種の企業が緑地保全 活動を実施し始めている。しかし企業の利益に直 接に結びつきにくい活動は，経営状況に左右され る傾向がある。企業社員が参加する緑地保全活動 が継続されるためには, 社会的貢献度だけでなく, 実施企業への効用も明らかにされることが必要で あろう。 
現代の高ストレス社会において，市民や企業社 員にはストレス解消のための活動が必要であろう。 先に示したように森林セラピーには健康回復に効 用があることが示さており，緑地の中の保全活動 には，同様の効用があることが期待されている. 緑地保全活動の新たな効用を示すことにより，健 康への意識の高い人々の関心をひきつけ，荒廃す る緑地を管理する活動者を増やすことができる可 能性がある。また企業社員を対象として心理的な 新たな効用を示すことにより，社員の福利厚生を 求める企業が，社会貢献活動と社員の健康回復を 同時に実現できることから，新たに参加する可能 性があると考える。

\section{2. 研究目的と対象・方法}

\section{1. 研究の目的}

本研究の目的の第 1 は, 緑地保全活動が市民ボ ランティアに与える心理的影響を示すこと，第 2 は，緑地保全活動が企業社員に与える心理的影響 を示すことである。そしてこれらの緑地保全活動 を運営する NP0 法人スタッフに与える心理的影響 を示すことが，第 3 の目的である。

2.2. 研究対象

研究の対象となるフィールドは，東京都八王子 市の滝山里山保全地域と，東京都日野市のなな山 緑地である。

そして研究目的を達成寸るために研究対象を 3 つ設定する．1つ目は，滝山里山保全地域の市民 による緑地保全活動であり，その市民活動をコー ディネート寸る NP0 法人のスタッフである. 2 つ 目は，同じ場所で，同じ団体の指導の下で実施さ れる企業による緑地保全活動に参加する企業社員 である。そして 3 つ目は，なな山緑地の緑地保全 活動に参加する市民ボランティアである.

\section{3. フィールド概要}

（1）滝山里山保全地域

滝山里山保全地域は 2013 年に里山保全地域と して指定され，JR 八王子駅北口からバスで約 15 分の場所に位置する。多摩川沿いの滝山丘陵の一 部で，近くには東京で唯一の道の駅である「道の 駅八王子滝山」もあり，古くからの住宅地と新し い住宅地が混在している。面積は約 4 ヘクタール の谷戸地形の中に，二次林と田んぼ，草地，竹林 が拡がっている。二次林には一部針葉樹林がある
が，落葉広葉樹林が大部分を占め，萌芽更薪され ずに大径木化が目立ち，林床が暗くなり，荒廃が 目立つ状況であった。だが活動団体により除伐， 下刚りされ，以前の姿を取り戻しつつある。同様 に田んぼも休耕田だったものが，開墾され数年が 経過し，田んぼまたは草地として良好な状態が維 持されている。

緑地保全活動を主催しているのは，NPO 法人自 然環境アカデミーである．当団体は，主に鳥獣類 の保護を目的とした市民団体であり，設立以来 20 数年が経過している。本活動は東京都からの依頼 に応える形で平成 24 年度から活動を開始した. 現 在, NPO 法人を中心として, 地域の自然保護団体, 地域自治会，企業社員などが一緒に緑地を保全し ている.

（2）なな山緑地

なな山緑地の正式名称は和田緑地保全の森であ り，特別緑地保全地区に指定されている。京王線 の聖蹟桜ヶ丘駅または高幡不動駅からバスで約 10 分の場所に位置し，面積は約 3 ヘクタールである。 近くには帝京大学やURにより分蚊開発された住 宅団地などがあり，本緑地は開発を免れた残存地 であり, 昭和 30 年代頃までは薪炭や近郊の畑地一 の堆肥の供給源として活用されていた。 その後土 地所有者の意向により，自治体に寄贈され，現在 は市民団体により管理がされている。緑地は，二 次林，竹林，小さな畑地や広場等から形成されて いる。 二次林には萌芽更薪されなかった大径化し た落葉広葉樹林が大部分を占めるが，針葉樹林や 常緑樹林なども存在する，林床の多くは市民によ り良好に管理され，見通しが確保された箇所もあ るが，整備をしないでアズマネザサを林床に繁茂 させた箇所も存在する

緑地保全活動を主催しているのは，なな山緑地 の会である．当団体は，多摩市の依頼に応える形 で当緑地を管理し始め，現在 16 年目を迎え，市内 外から会員を集め, 現在 50 名ほどの会員が存在す る。本緑地での保全活動が主な活動となるが，小 学生を緑地に招く，または自ら会員が出向くなど, 自然体験活動の普及にも力を入れている.

\subsection{3 つの研究対象}

(1) スタッフの活動

研究の対象となるのは, 滝山里山保全地域で行 われる市民活動を運営する NP0 法人のスタッフで ある。月に少なくとも 1 回の定例活動が行われ， 
NP0 法人の会員, 地域の自然保護団体や自治会に 所属する地域住民が参加する．参加者は高齢者の 男性が多いが，スタッフの年齢は 40 歳代〜60 歳 代と幅が広く，長期に活動している男性である. スタッフは主催者として保全活動を取り仕切り, または活動を安全に行うために様々な作業の支援 を行っている. 常時 2 5 名程度が参加し, 運営ま たは運営補助に当たっている。

（2）企業社員の活動

研究の対象となるのは, 滝山里山保全地域で行 われる，東京都が主催する企業の緑地保全活動を 促進させるグリーンシップ・アクションに応募し たハウスメーカーの社員である. 2014 年度から滝 山里山保全地域での活動を開始し，5年目を迎え ている．社員は 20 歳代〜 50 歳代と若い世代が多 く, はじめての参加者から 5 年目の参加者もおり， 幅が広い。男性と女性の比率は約 7:3 である。

（3）市民ボランティアの活動

研究の対象となるのは，なな山緑地の保全活動 に参加する市民ボランティアである．参加者の多 くは 65 歳以上の高齢者であり, 長期間活動してい る者が多い。男性と女性の比率は約 7:3 である。

\section{5. 研究手法}

質問紙を保全活動前と活動後に配布し，参加者 に回答してもらい，活動前後の比較検証を行う. 質問紙は，参加者の心理的影響を計測する心理的 指標の POMS 短縮版質問項目を使用する.これは, 緊張 - 不安, 抑うつ - 落ち込み, 怒り - 敵意, 活 気，疲労，混乱の 6 項目から構成され，各尺度は 5 つの変数から成り, 合計 30 個の質問がある. 活 気尺度は，回答值が高いほど活気があることを， それ以外の尺度は，回答值が高いほど心理ストレ ス度が高いことを示している。

\section{3. 研究結果と考察}

\subsection{3 つの対象の活動内容}

(1) スタッフの活動

研究対象となったスタッフの活動は，2017 年〜 2018 年の 4 月から翌 3 月の 1 年間で，NP0 法人の 運営に支障がある期間を除いた，4月，5月，6月， 7 月， 9 月， 10 月， 11 月， 11 月， 1 月， 2 月， 3 月 の 11 回であった. 対象となったのは, のべ 31 名 のスタッフであり, 市民活動の参加者は毎回 10 名 程度であった。多くの活動時間は午前中 9 時〜 12 時の 3 時間であり，主な活動内容は，草刈り，田
植え，稲刈り，竹や樹木の伐採，植物の移植，畑 仕事，道作りなどであった。

（2）企業社員の活動

研究対象となった企業社員の活動は，2017 年の 6 月，11月の 2 回であり，対象となったのは，の べ 51 名の企業社員であった。活動時間は 10 時か ら尽飯を挟んで 15 時までの 4 時間であり, 主な活 動内容は田植えと稲刈りなどであった。

（3）市民ボランティアの活動

研究対象となった市民ボランティアの活動は, 2017 年〜2018 年の 7 月，11月，2 月，4 月の 4 回 であり，対象となったのは，のべ 65 名の市民ボラ ンティアであった。活動時間は 9 時から昼飯を挟 んで 15 時までの 5 時間であり，主な活動内容は， 道作り，草刈り，樹木の伐採，落ち葉掃き，畑の 整備などであった。

\section{2. 分析手法}

緑地保全活動に参加することで参加者にどのよ うな変化があらわれるのかを示すために，POMS 短 縮版の回答值について，活動前調查と活動後調查 の回答值の平均值を検証した.

それぞれの尺度における平均值は，構成する 5 つの変数の回答值を合計し，その変数の数で除し て，先ず各回答者の尺度の平均值を出した．次に それらを合計し, 回答者数で除して算出をした。

\section{3. 研究結果}

（1）各研究対象の活動前後の平均值の比較

スタッフの活動，企業社員の活動，市民ボラン ティアの活動別に，それぞれの尺度について活動 前調查, 活動後調查の回答值の平均值を検証した。 また統計上，活動前と活動後の平均值に差が生じ るか，t検定をした。

その結果をまとめたものを表 1 に，またそれぞ れの研究対象における尺度毎の活動前調査，活動 後調査の回答值の平均值を記載したものを図 1〜 3 に示す.

表 1. 研究対象の活動前後の回答值の平均值

\begin{tabular}{|c|c|c|c|c|c|c|c|c|c|}
\hline & \multicolumn{3}{|c|}{ スタッフの活動 } & \multicolumn{3}{|c|}{ 企業社員の活動 } & \multicolumn{2}{|}{ 民ボランティアの活動 } \\
\hline POMS & 活動前 & 活動後 & $\begin{array}{c}\text { 有意 } \\
\text { 確率 }\end{array}$ & 活動前 & 活動後 & $\begin{array}{c}\text { 有意 } \\
\text { 確 }\end{array}$ & 活動前 & 活動後 & $\begin{array}{c}\text { 有意 } \\
\text { 確 }\end{array}$ \\
\hline $\begin{array}{c}\text { 緊張-不安 } \\
\text { 茳うつ- } \\
\text { 落ち込み }\end{array}$ & 0.60 & 0.45 & 0.10 & 0.52 & 0.04 & 0.00 & 0.70 & 0.26 & 0.00 \\
\hline 怒り-敵意 & 0.03 & 0.22 & 0.01 & 0.16 & 0.02 & 0.02 & 0.09 & 0.01 & 0.00 \\
\hline 活気 & 1.66 & 1.28 & 0.00 & 1.60 & 1.83 & 0.06 & 1.91 & 2.02 & 0.21 \\
\hline 疲労 & 0.26 & 0.95 & 0.00 & 0.42 & 0.53 & 0.26 & 0.35 & 0.80 & 0.00 \\
\hline 混乱 & 0.91 & 0.96 & 0.39 & 0.51 & 0.27 & 0.01 & 0.91 & 0.71 & 0.00 \\
\hline
\end{tabular}


企業社員と市民ボランティアの回答值では, 活 気と疲労において, 活動後調査の回答值が活動前 調查と比較し上昇し，それ以外の 4 つの尺度にお いて，下降していた。また企業社員の疲労，市民 ボランティアの活気以外の尺度において， 5 パー セント (※※) または 10 パーセント（※）水準で 有意差がみられた。

一方でスタッフの活動の回答值では, 緊張 - 不 安において, 活動後調査の回答值が活動前調査と 比較し下降したものの, 抑うつ - 落ち込み, 怒り - 敵意, 疲労, 混乱において，上昇しており，ま た活気においても，下降していた。 そして混乱以 外の尺度において 5 パーセント（※※）または 10 パーセント（※）水準で有意差がみられた。

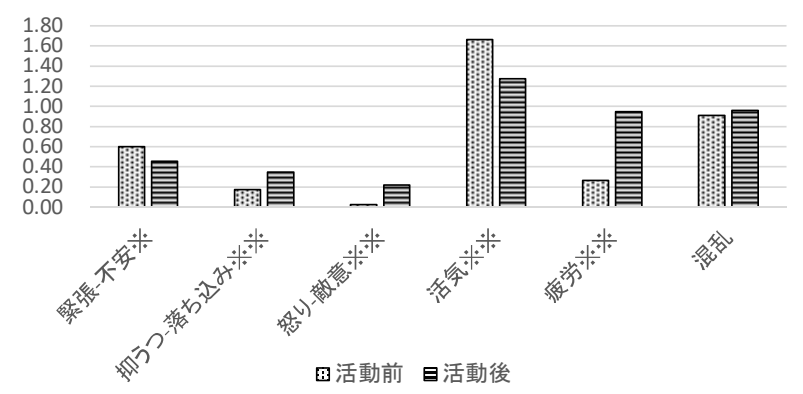

図 1.スタッフの活動前後の回答值の平均值

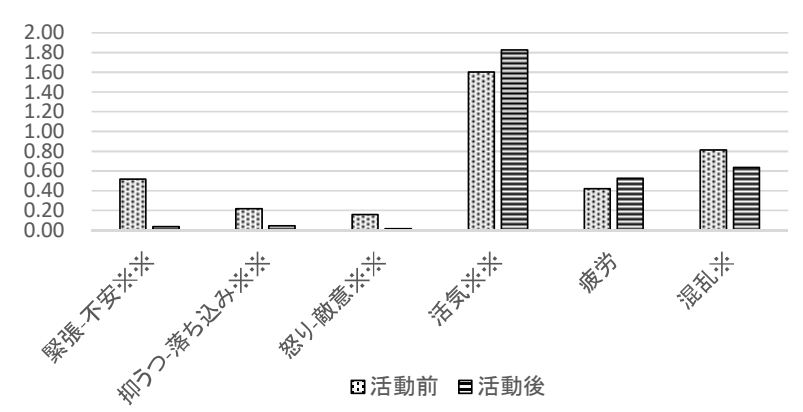

図 2. 企業社員の活動の回答値の平均値

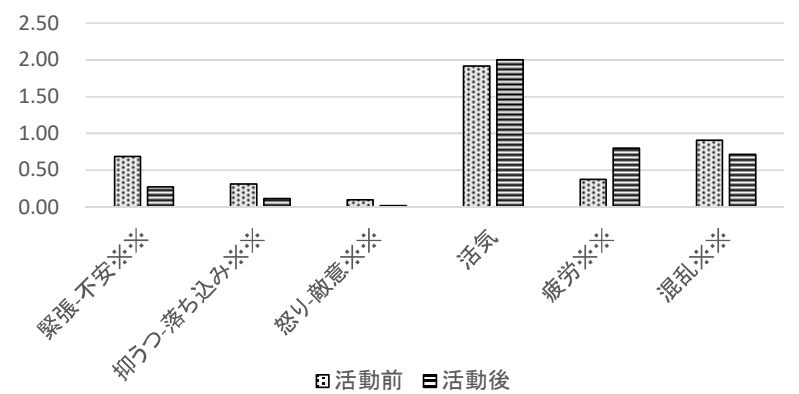

図 3. 市民ボランティアの活動の回答值の平均値

以上の結果より, スタッフの回答値の変化傾向 を表すスタッフ型と, 企業社員と市民ボランティ アの回答值の変化傾向を表す企業市民型の 2 つの タイプに分類される. 両者に共通する特徴は, 緊
張 - 不安において，活動後調査の回答值が活動前 調査と比較し下降し，疲労において，上昇したこ とである。そしてスタッフ型では，抑うつ－落ち 込み, 怒り一敵意, 混乱において, 活動後調查の 回答值が活動前調査と比較し上昇し, 活気におい て，下降した。一方で企業市民型では，抑うつ落ち込み, 怒り - 敵意, 混乱において, 活動後調 查の回答值が活動前調査と比較し下降し, 活気に おいて，上昇した。

（2）2つのタイプの活動前後の差の比較

そこでスタッフ型と企業市民型の概要を示寸た めに，3つの調查対象を 2 つに分類し，それぞれ の活動後調查から活動前調查の回答值を引いた差 の平均值を算出し, 2 つのタイプに差が生じるか $\mathrm{t}$ 検定をした。その結果をまとめたものを表 2 に, また尺度毎の差が上昇したもの，下降したものに 分類して示したものを図 4 に示す.

表 2. スタッフ型と企業市民型の活動前後差の比較

\begin{tabular}{|c|r|r|r|}
\hline POMS & \multicolumn{1}{|c|}{ スタッフ型 } & \multicolumn{1}{c|}{ 企業市民型 } & 有意確率 \\
\hline 緊張-不安 & -0.15 & -0.44 & 0.00 \\
\hline 抑うつ-落ち込み & 0.19 & -0.19 & 0.00 \\
\hline 怒り-敵意 & 0.15 & -0.11 & 0.00 \\
\hline 活気 & -0.37 & 0.14 & 0.00 \\
\hline 疲労 & 0.62 & 0.29 & 0.03 \\
\hline 混乱 & 0.05 & -0.19 & 0.00 \\
\hline
\end{tabular}

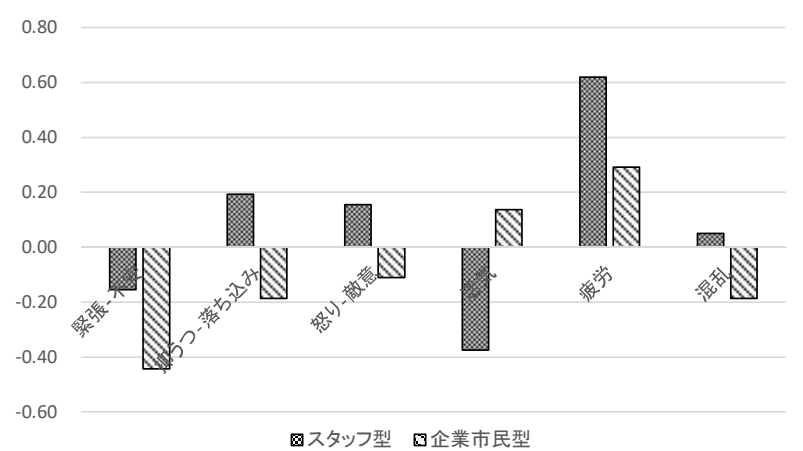

図 4. スタッフ型と企業市民型の活動前後差の比較

活動後調查の回答值が活動前調査と比較し下降 したのは，スタッフ型では緊張 - 不安, 活気，企 業市民型では緊張 - 不安，抑うつ - 落ち込み，怒 り - 敵意，混乱であった。逆に上昇したのが，ス タッフ型では抑うつ - 落ち込み, 怒り - 敵意, 疲 労, 混乱, 企業市民型では活気, 疲労であった。

そしてスタッフ型と企業市民型の活動前後差に はすべての尺度において，5\%水準で有意差がみら れた。 


\section{4. 考察}

2 つのタイプに共通するのは, 緊張 - 不安にお いて, 活動後調査の回答值が活動前調查と比較し 下降，疲労において，上昇していることである。 だがその変化の幅には差がある，活動することに より，両者ともに緊張 - 不安から解消されている が，企業市民型の方が変化值は大きく，その解消 度合が高いと言える。また両者ともに疲労が増加 しているが，スタッフ型の方が変化值は大きく, スタッフとして活動することはボランタリーに活 動する以上に肉体的に疲労することが推測される.

一方でその他の尺度の抑うつ - 落ち込み, 怒り 一敵意, 活気, 混乱において, 両者は異なる結果 となった．企業市民型では，活動したことで身体 的に疲労した以外は, 森林セラピーと同様に参加 者に心理ストレスの減少や活気をもたらす傾向が あることが示された，だがスタッフ型では，活動 を運営などすることで身体的に疲労し, 心理的に は活気が減少し, 心理ストレス度も高くなる傾向 があることが示された。

\section{謝辞}

本研究に多大なるご協力をくださった NP0 法人 自然環境アカデミーの皆様には感謝を申し上げま す.また，緑地保全活動に参加させていただき， 調查に協力頂いたなな山緑地友の会の皆様，企業 社員の皆様にも感謝申し上げます。

\section{付記}

本稿は平成 29 年度大妻女子大学戦略的個人研 究費の採択課題「緑地保全活動の心理的 - 生理的 な効用」（課題番号 S2924）の助成を受けた研究成 果の一部である。

\section{引用文献}

[1]宮崎良文. 日本における森林医学研究. 日衛 誌. 69, 2014, p. 122-135.

[2] 中川重年. 森づくりテキストブックー市民によ る里山林・人工林管理マニュアルー, 山と溪谷社, 2004, p. 14-16.

\section{Abstract}

The purpose of this research is to show the psychological effect of green conservation activities to citizen volunteers, corporate employees and non-profit organization staff. Therefore, I set three research subjects in the two fields in Tokyo metropolitan area. Then, I investigated by POMS shortened version consisting of 6 scales before and after conservation activities. As a result, it was classified into staff type and corporate citizen type. In the corporate citizen type, there is a tendency for participants to decrease psychological stress and to bring liveliness like participation in forest therapy, although physical fatigue by acting. However, in the staff type, there is a tendency for participants to make them tired physically, diminish liveliness and increase psychological stress by operating the conservation activities.

（受付日：2018 年 6 月 18 日，受理日：2018 年 7 月 4 日）

\section{甲野 毅（こうの つよし）}

現職 : 大妻女子大学家政学部ライフデザイン学科准教授

東京農工大学大学院・連合農学研究科・環境資源共生科学専攻修了 専門は環境教育学，造園学. 